\title{
Resident bacterial populations mediating biogeochemical dynamics in a Uranium roll front deposit
}

\section{Fadwa Jroundi ( $\square$ fadwa@ugr.es )}

Universidad de Granada https://orcid.org/0000-0003-3437-8119

\section{Michael Descostes}

Orano Mining

Cristina Povedano-Priego

Universidad de Granada

Iván Sanchez-Castro

Universidad de Granada

Vitthavat Suvannagan

Orano Mining

Pierre Grizard

Orano Mining

Mohamed L. Merroun

Universidad de Granada

\section{Research}

Keywords: Uranium, In-situ recovery, Bacterial diversity, Network analysis, Bioremediation, Natural attenuation.Uranium, In-situ recovery, Bacterial diversity, Network analysis, Bioremediation, Natural attenuation

Posted Date: January 21st, 2020

DOI: https://doi.org/10.21203/rs.2.17563/v2

License: (c) (i) This work is licensed under a Creative Commons Attribution 4.0 International License. Read Full License 
The authors have withdrawn this preprint from Research Square 